\title{
Nursing as a mediator between nomophobia and social isolation in response to COVID-19
}

\author{
Enfermagem como mediadora entre nomofobia e \\ isolamento social em resposta à COVID-19 \\ Enfermería como mediadora entre la nomofobia y el \\ aislamiento social en respuesta al COVID-19
}

\author{
Marcos Venicio Esper ${ }^{\mathrm{a}}$ \\ Jeferson Santos Araújo ${ }^{b}$ \\ Manoel Antônio dos Santos ${ }^{c}$ \\ Lucila Castanheira Nascimento ${ }^{a}$
}

How to cite this article: Esper MV, Araújo JS, Santos MA, Nascimento LC. Nursing as a mediator between nomophobia and social isolation in response to COVID-19. Rev Gaúcha Enferm. 2021;42(spe):e20200292. doi: https://doi.org/10.1590/19831447.2021.2020-0292 a Universidade de São Paulo (USP), Escola de Enfermagem de Ribeirão Preto, Centro Colaborador da OPAS/OMS para o Desenvolvimento da Pesquisa em Enfermagem. Ribeirão Preto, São Paulo, Brasil.

b Universidade Federal da Fronteira Sul (UFFS), Faculdade de Enfermagem. Chapecó, Santa Catarina, Brasil.

Universidade de São Paulo (USP), Faculdade de Filosofia, Ciências e Letras de Ribeirão Preto. Ribeirão Preto, São Paulo, Brasil.

\section{ABSTRACT}

Objective: To reflect on the relationship between the nomophobia and the pandemic of COVID-19 and the nursing contributions to deal with this issue and its consequences.

Method: This reflective and theoretical study was based on the dialogue between the scientific literature on the subject and in dialogue and conceptual perspective of comprehensive care.

Results: Nursing strives to harmonize observed problems and can support individuals to reflect and discover a potential harmful habit regarding the use of cell phones, especially when undergoing treatments for other diagnoses.

Final considerations: Nursing, when accessing the emotional and subjective aspects of those under their care, helps to alleviate the symptoms of nomophobia and, in tune with the patient, promotes harmony in the face of the COVID-19 pandemic.

Keywords: Cell phone use. Nursing. Pandemics. Coronavirus infections. Social isolation.

\section{RESUMO}

Objetivo: Refletir sobre a relação entre nomofobia e pandemia da COVID-19 e delinear as contribuições da Enfermagem para lidar com esta situação e suas consequências.

Método: Estudo teórico e reflexivo, fundamentado no diálogo entre a literatura científica sobre a temática e uma perspectiva conceitual da integralidade do cuidado.

Resultados: A Enfermagem pode apoiar a identificação e reflexão sobre um hábito prejudicial relacionado ao uso inadequado do telefone celular, principalmente quando os indivíduos estão em tratamento para outros diagnósticos.

Considerações finais: A Enfermagem, ao abordar os aspectos emocionais e subjetivos das pessoas sob seus cuidados, pode auxiliar no alívio dos sintomas da nomofobia e, em sintonia com as necessidades do paciente, contribuir para maior segurança, redução do estresse e identificação de estratégias promotoras de bem-estar neste contexto de pandemia.

Palavras-chave: Uso do telefone celular. Enfermagem. Pandemias. Infecções por coronavírus. Isolamento social.

\section{RESUMEN}

Objetivo: Reflexionar sobre la relación entre la nomofobia y la pandemia de COVID-19 y las posibles contribuciones de Enfermería para abordar este tema.

Método: Este estudio teórico y reflexivo basado en el dialogo entre la literatura científica sobre el tema y una perspectiva conceptual de la atención integral.

Resultados: La enfermería se esfuerza por armonizar los problemas observados y puede ayudar a las personas a reflexionar y descubrir un posible hábito perjudicial con respecto al uso de teléfonos celulares, especialmente cuando se someten a tratamientos para otros diagnósticos.

Consideraciones finales: La enfermería, al acceder a los aspectos emocionales y subjetivos de las personas bajo su cuidado, ayuda a aliviar los síntomas de la nomofobia y, en sintonía con el paciente, promueve la armonía frente a la pandemia de COVID-19.

Palabras clave: Uso del teléfono celular. Enfermería. Pandemias. Infecciones por coronavirus. Aislamiento social. 


\section{口INTRODUCTION}

In this study, nomophobia will be treated as dependence that may lead to a psychopathological condition, considering the fine line between need and dependence regarding the use of information and communication technologies (ICTs). The use of remote contact devices has increased considerably since the start of 2020, when the world was confronted with the pandemic caused by the novel coronavirus (SARS-CoV-2). COVID-19 paralyzed economic activities and led health care authorities to decree measures that restrict the free circulation of people. Adherence of the population to social distancing is directly related to the perception of the risk of infection and exposure to health hazards. However, when not conducted harmoniously, social isolation threatens people's psychosocial and emotional balance, which can trigger stress, anxiety, anger, boredom, and even a sense of exile from the rest of the world $^{(1)}$. During the pandemic, people increased their use of electronic devices, especially mobile phones, in an attempt to mitigate the negative consequences of social isolation, reduce the impacts of these feelings, and connect with the world, while safeguarding the need for social distancing.

As a consequence, the number of studies reporting the harmful effects of the excessive use of mobile devices on mental and physical health is also steadily growing ${ }^{(2-3)}$. $\mathrm{Al}-$ though a debate on whether the excessive use of mobile phones can be understood as a behavioral addiction persists in the literature and although the same phenomenon is often described with different terms, such as problematic or excessive use of mobile phones, mobile phone addiction has generally been conceptualized as a behavioral addiction, characterized by the basic symptoms of additive conduct(2).

Because of the current social isolation imposed to prevent the virus from spreading, the growing number of users logged onto the Internet, and increased time spent online, it is important to view the problem of hyperconnectivity from the perspective of an imbalance, an abnormal situation, and as the phenomenon known as nomophobia ${ }^{(3)}$. The gradual restoring of activities and return to regular circulation is believed to characterize a transition period to a post-pandemic world, in which restrictive measures can last for an undetermined time. This transition of post-social isolation and unpredictability as to the feasible or unfeasible return to normal activities creates a scenario of uncertainties that also interferes with people's mental health.

Thus, based on the experience of the researchers and the current literature, this study was developed to encourage reflection and discussion on how nurses can intervene in this problem and, at the same time, mitigate factors arising from nomophobia experienced by people in their care. Historically, nurses have acted as protagonists in the care of other compulsive disorders, such as the abusive use of psychoactive substances, including alcohol and tobacco, pathological gambling and shopping compulsion, and, more recently, they have become outstanding frontline professionals in the care of people affected by COVID-19. Thus, it is considered that the professional category has the expertise needed to promote and control health in a collective and individualized context, including conducting educational campaigns, implementing public policies, and offering care. However, the ability to identify nomophobia still depends on more and better evidence, conceptual clarification, training, and scientific support through research on the subject, which denotes the relevance of this study.

In order to propose an interposition between nursing care and nomophobia, a discussion based on the concept of comprehensive care was given priority, especially in terms of integrating healthcare activities and services to assist individuals in their plural needs, under the influence of biopsychosocial factors ${ }^{(4)}$. In this context and considering the absence of evidence that summarizes the consequences of nomophobia during the current COVID-19 pandemic, this study was guided by the following question: What are the possible relationships between nomophobia and the current COVID-19 pandemic?

\section{$\square$ METHOD}

This is a theoretical and reflective study, based on the conceptual perspective of the comprehensiveness of care $^{(4)}$. Comprehensive care consists of four structuring and inter-dependent axes that instrumentalize care-oriented health services, namely 1) needs: all issues related to initial assistance and response to human needs, not limited to functioning of the biological body; (2) purposes: all activities related to health promotion, disease prevention, treatment, and social re-integration; (3) coordination: related to the structure of the training, know-how, and interdisciplinary studies, multi-professional teams, and activities for the development and provision of effective care for an extended perspective of needs; and (4) interaction: all problem-solving activities for the quality and nature of care provided, based on the capacity for dialogue between all those involved, to ensure the conditions for implementing the previous axes. In this study, the four axes that structure comprehensive care guided and supported the discussion presented in this reflection ${ }^{(4)}$.

This text was divided into two parts. The first part addresses topics of social isolation and the use of mobile phones for 
communication and social interaction at a distance, while the second part combines the subjects of nomophobia, social distancing, and nursing.

\section{RESULTS}

\section{The use of mobile phones during social isolation: protective resource or vulnerability factor?}

As discussed earlier, the pandemic contributed to the negative impacts of excessive use of mobile devices. Evidently, the function of mobile phones is not to foster compulsive behaviors, but rather to enable progressive interaction based on specific features and a range of interactive resources for communicating, obtaining information, and amusement. This habit causes some people to become increasingly connected and dependent on their mobile phones and, in some cases, causes them to become frustrated and acutely anxious when they are unable to use their phones ${ }^{(5-6)}$.

In general, addiction and dependence are considered synonyms, however, according to the National Institute on Drug Abuse ${ }^{(6)}$, the term addiction is usually used to describe the behavior of people who have a physical need to consume alcohol, tobacco, and other substances in excess or any exaggerated behavior considered repetitive and self-destructive. In contrast, dependence is related to the psychological need of the user and may or may not be associated with compulsion in the same person. Nomophobia, while it may be considered a disorder, refers to craving-like behavior observed in users when abstaining from substance use ${ }^{(1)}$.

In the Americas, nomophobia can be considered a public health problem although it has not been included in the Diagnostic and Statistical Manual of Mental Disorders (DSM-5), widely used to evaluate and diagnose psychiatric illnesses ${ }^{(7)}$. The growing interest in this problem has increased expectations that the symptomatology will be recognized as a specific phobia. The DSM-5 already contains an appendix on internet gaming addiction, a disorder unrelated to substance use, which may, in the near future, encourage the expansion to a more formal characterization of the abuse of $I C T s^{(7)}$ and an extended consideration from the standpoint of comprehensive care. However, while a consensus for diagnostic criteria is not established, standardized instruments and questionnaires have been created to classify patients regarding excessive use of mobile phones, as in the case of the Smartphone Addiction Scale (SAS), the Mobile Phone Problem Use Scale, and the Problematic Cellular Phone Use Questionnaire (PCPU-Q), which seek to measure the extent of ICT use in the daily lives of respondents ${ }^{(7)}$.
It should be noted that psychopathology is not triggered by the device itself, but by the excessive behavior of users. The function of a mobile phone is not to foster compulsive behaviors, which alienate the subject from reality; however, due to the increasing features and variety of interactive resources of communication, information, and entertainment that it offers, a virtual world had been created based on the progressive interaction between people and machines.

From the first months of 2020, when the world was confronted with an unexpected emergency caused by the pandemic of the novel coronavirus, these devices started to be used more often. According to the United Nations $(U N)^{(8)}$, COVID-19, in a period of only five or six months, submerged the world into the worst humanitarian crisis ever experienced since World War II.

From March 27 to September 25, 2020, Brazil recorded 140,709 deaths from COVID-19. According to a report released by the Ministry of Health, the United States topped the list of infection cases, followed by India and Brazil. Considering global infection rates and potential mortality due to the absence of effective treatment or a vaccine for the virus, the number of deaths caused by COVID-19 is expected to reach an alarming 2.8 million. However, if the government is lenient toward social distancing policies, fatal victims could rise to 3.9 million. So far, the only way to mitigate this catastrophic outcome is by intensifying social distancing measures and take standard precautions, such as the use of face masks, regular hand washing, and the use of 70\% alcohol-based hand sanitizers( ${ }^{(8)}$.

Social distancing, when prolonged, can trigger psychoemotional problems, especially among people who maintain physical contact habits (hugs, handshakes, kisses, among others) and those who have pre-existing psychological symptoms. In these cases, ICTs can help mitigate the impacts of isolation, provided they are used appropriately as a tool to bridge distances and enable protected social contact through interactions and moments of virtual presence that help people move on with their lives.

The contemporary world is constantly changing and, as occurs in times of war, revolutions, and cataclysms, some opportunities have been created for people to reorganize time, space, relationships, and other learning processes and work routines and, consequently, rethink their choices and paths. It is therefore an opportune moment for the identification of alternative solutions that allow people to maintain or modify certain activities and relationships. In this regard, some people, in the hope of promoting a culture of effective community care, have been taking part in online meetings, solidary activities, gaming, and entertainment, and sharing messages via WhatsApp, Instagram, Facebook, and 
other applications. Moreover, some use these resources to learn and acquire new technical, logistical, and managerial skills for health care practices, leading to the increasing use of digital networks that existed prior to the pandemic for different purposes.

Researchers ${ }^{(2,6)}$ also stress the need to accompany the profile of each user and monitor average hours/day they remain connected in order to identify any dependence, which is when users are between an hour and a half (minimum) and four to 10 uninterrupted hours or, on average, 38 hours per week on their devices. Virtual relationships can provide a sense of control and security to users due to the anonymity and guaranteed physical distancing, thus reducing exposure to risks.

\section{Nomophobia as a consequence of social isolation: What does nursing have to do with it?}

The essence of nursing is hands-on care. One of the benefits of nursing, which is the application of theoretical parameters to promote comprehensive care, is the capacity to monitor health status and encourage observance of self-care parameters ${ }^{(9)}$. Self-care is the act of taking care of oneself and seeking the necessary tools to protect the body and mind and improve our physical and mental health. However, selfcare and comprehensive care may be compromised by the excessive use of mobile phones when users lose interest in performing other activities considered especially pleasant by other people. Furthermore, the excessive use of mobile phones can lead to the inability to perform tasks, reduced attention and concentration, increased hopelessness and skepticism, and permanent sadness, among other adverse outcomes. In the current context, in which the onset of these symptoms may be triggered by the uncontrollability caused by the emergence of an invisible threat, nurses must not only treat these diseases but also help prevent them.

In this regard, nurses can encourage reflections on the excessive use of mobile phones by addressing the issue during their routines and promoting a therapeutic alliance on the time of use of devices at the hospital and in the community with users and their families. Based on this information, they can encourage users to engage in healthy habits and provide advice to reduce the risks of illness.

Several databases in the area of health care (PubMedlinked to the US National Library of Medicine, National Center for Biotechnology Information, and National Institutes of Health) provide access to more than 4,500 published papers about COVID-19 and SARS-CoV-2(10). This set of scientific knowledge points out, in a unified and unique way, that maintaining social isolation measures is critical to mitigate the spreading of the disease and manage comprehensive care in assistance and social control networks ${ }^{(11)}$. Similarly, it is projected that prolonged social isolation may increase the risk of developing symptoms of nomophobia. Thus, it is relevant to involve nursing in actions that mitigate possible damages arising from excessive use of mobile phones, increased virtual connectivity, and the use of social media and ICTS. Professionals should be aware that a prohibitionist approach is not the most recommended strategy in the treatment of compulsions, but integrated approaches through support systems that include knowledge from health workers, users, and the community can provide better results.

In addition, attitudes such as acceptance and empathy are more appropriate for establishing a good bond between nursing professionals and patients. Interaction should be permeated by positive communication that provides benefits and helps people cope and adapt to the adverse circumstances imposed by social isolation, thus possibly preventing people from finding refuge exclusively in mobile devices, which may lead to nomophobia. It is important to help these users restore their confidence in genuine human relationships, including those established by ways other than virtual ones.

Moreover, the management of patients undergoing treatment for COVID-19 infection should include psychosocial and emotional assessments to detect symptoms of nomophobia, obsessive compulsive disorder (OCD), hypervigilance, among others, as provided for in the protocol for clinical management of coronavirus (COVID-19) in primary health care, adopted by the Brazilian government. However, although it is recognized that such outcomes may be aggravated in the pandemic, to date, there is no precise evidence on the natural history of the new disease (COVID-19) or effective measures for the clinical management of cases of human infection, which reveals numerous gaps remaining to be clarified ${ }^{(12)}$.

From the perspective of comprehensive care, this management should consider the actions and health services aimed at understanding the phenomenon as a whole and ensure comprehensive care to each person through management plans and care articulated in a clinical perspective $e^{(4)}$. Thus, in an environment of great tension, one can expand the preventive scope in relation to nomophobia and formulate new perspectives for integral health promotion.

\section{Implications for nursing practice}

Although mobile phone applications are not a novelty in health care, they are being increasingly used in different health-related scenarios, such as primary care; hospital and rescue situations and aeromedical transport; situations in 
which the professional is embarked on an oil platform; and in contexts in which remote work and communication have become exclusively online, including as a support tool for telehealth services, to facilitate visits and consultations; follow-up of bedridden patients via FaceTime and provision of access to health institutions, such as COVID-PassID, in the United States ${ }^{(12)}$. In these cases, technology is used to potentiate a new praxis for the production and promotion of health care, which allows professionals to go beyond the purely physical clinical approach and enables comprehensive care that includes the recognition of patient rights, the signs of their culture, and their subjectivity ${ }^{(4,13)}$.

In the context of social isolation, people can also receive care from nursing professionals through messages, audio or video calls, and phone calls, with guidelines that promote collective care and encourage families to interact proactively and possibly prevent compulsive behaviors, such as the pathological use of mobile phones by their members, as a way of mediating therapeutic discussions and promoting mental health.

Primary care practices are, in fact, a continuum of care since they not only target disease prevention, health promotion, disease management, and health education but also focus on all dimensions of health care. In the pandemic, a specific clinical protocol has been adopted ${ }^{(12)}$ that highlights the following steps: identification of suspected cases of influenza syndrome and COVID-19, measures to avoid contagion in the basic health unit (UBS), and stratification of the severity of the influenza syndrome. For mild cases, the recommendation includes therapeutic management and home isolation and, for severe cases, stabilization and referral to emergency or hospital services, immediate notification, clinical monitoring and community prevention measures, and active surveillance support ${ }^{(12)}$.

In this context, some technical actions are important in terms of resolvability, with the aim of providing coping and behavior guidelines for primary care users and workers, however, without mention of psychosocial and emotional issues and factors. Therefore, a broad and all-encompassing educational practice inspired by comprehensive care should be adopted ${ }^{(4,1,1,13)}$, with recommendations on the appropriate use of mobile devices during a pandemic, emphasis on strengthening family ties and bonds between members who stay at home to the detriment of mobile devices, and guidelines on the need for adjustment and reorganization of routines and habits. It is necessary to promote new adaptations to reality that are not based on the prolonged use of mobile phones, among other practices that can be carried out in specific contexts $s^{(9,13)}$. From a perspective of comprehensive care, with the support of the multiprofessional team, health institutions, and the community, it is possible to plan lines of care that guarantee and legitimize an environment where everyone is responsible for protection, management, and coordination measures at different points of health care $^{(4,11)}$.

Patients affected by COVID-19 need to be treated in isolation at the hospital, which represents one of the most painful facets of the disease, considering the compulsory removal of family members from the care environment. Therefore, nursing professionals should provide guidelines to such patients on the use of mobile phones in the hospital and establish criteria that harmonize access to health in a humanized way and strengthen human connections, as recommended by the structuring axes of comprehensive care ${ }^{(4,13)}$.

Although the Federal Constitution ${ }^{(13)}$ and the Brazilian Nursing Council(14) prohibit the use of unauthorized images, patients are advised not to take photos of any person without permission, for example, including employees or companions in waiting rooms. Taking photos or recording videos without permission can violate the privacy of another patient or companion and cause great discomfort. In this regard, precautionary measures should also be taken to make video calls, so that other patients, visitors, or staff members are not inadvertently seen by others. It is also forbidden to make calls or use phones in a manner that violates the right to rest of other patients, as well as use mobile phones near sensitive equipment, in which there is a risk of interference and malfunction.

In contrast, potential benefits can also be attributed to the use of mobile phones among inpatients, such as facilitating communication with family and friends, providing psycho-emotional support and comfort to mitigate the isolation during the hospital stay, and the recording of conversations when duly authorized by health workers to help reduce anxiety.

In any context, especially in the case of patients in medium and high-risk situations who may be unaware of the ethical aspects involved in their actions, nurses should develop educational practices that encourage reflection and promote the well-being of all those involved. This includes specific recommendations for the proper use of mobile phones in hospital or community settings, thus strengthening organizational arrangements of comprehensive care actions and services. 


\section{FINAL CONSIDERATIONS}

Nomophobia can be considered a psychopathological condition, especially when digital devices are used to escape feelings of discomfort, stress, anxiety rather than provide pleasure and personal growth. Reflection on the use of information and communication technologies in a non-harmonious way in the current pandemic reiterates the need to instrumentalize technology at the service of health promotion. In this regard, nursing professionals can and should use their knowledge to address the emotional and subjective aspects of patients and, thus, help in the perception and reduction of vulnerability to the symptoms of nomophobia, based on the provision of extended and comprehensive care. Through receptiveness, understanding, and dialog with patients, nurses can strengthen their resources to better cope with the challenges imposed by the COVID-19 pandemic.

\section{REFERENCES}

1. Lin Y, Chiang C, Lin P, Chang L, Ko C, Lee H, et al. Proposed diagnostic criteria for smartphone addiction. PloS One. 2015;11(11):e0163010. doi: https://doi. org/10.1371/journal.pone.0163010

2. Ivanova A, Gorbaniuk 0, Agata B, Przepiórka A, Mraka N, Polishchuck V, et al. Mobile phone addiction, phubbing, and depression among men and women: a moderated mediation analysis. Psychatr Q. 2020;91(3):655-68. doi: https://doi. org/10.1007/s11126-020-09723-8

3. Shoukat, S. Cell phone addiction and psychological and physiological health in adolescents. EXCLI J. 2019;18:47-50. doi: https://doi.org/10.17179/ excli2018-2006

4. Kalichman, A0, Ayres, JRDCM. Integralidade e tecnologias de atenção à saúde: uma narrativa sobre contribuiçōes conceituais à construção do princípio da integralidade no SUS. Cad Saúde Pública. 2016;(32):e00183415. doi: https:// doi.org/10.1590/0102-311X00183415
5. Mengi A, Singh A, Gupta V. An institution-based study to assess the prevalence of Nomophobia and its related impact among medical students in Southern Haryana, India. J Family Med Prim Care. 2020;9(5):2303-8. doi: https://doi.org/10.4103/ jfmpc.jfmpc_58_20drugabuse.gov [Internet] Bethesda: National Institute on Drug Abuse; 2020 [cited 2020 May 11]. Available from: https://www.drugabuse.gov

6. King ALS, Nardi AEC. Nomofobia: dependência do computador, internet, redes sociais? dependência do celular? 1. ed. São Paulo: Editora A; 2015.

7. World Health Organization (CH) [Internet]. Geneva: World Health Organization; c2020 [cited 2020 mai 21]WHO Director-General's opening remarks at the media briefing on COVID-19 - 11 March 2020; [about 1 screen]. Available from: https://www.who.int/dg/speeches/detail/who-director-general-s-openingremarks-at-the-media-briefing-on-covid-19---11-march-2020

8. Barbosa EV, Pantoja EA, Barbosa JV, Loiola BMM, Borges AA, Reis PFS, et al. Educação em Saúde sobre rede de cuidados a pessoa com deficiência: relato de experiência. Braz J Health Rev. 2020;3(4):8644-9. doi: https://doi. org/10.34119/bjhrv3n4-112

9. A pesquisa científica sobre coronavírus [dados]. Pesquisa FAPESP. 2020 [cited 2020 May 20];(290):11. Available from: https://revistapesquisa.fapesp. br/a-pesquisa-cientifica-sobre-coronavirus/

10. Gadamer DH. Uma concepção hermenêutica de saúde. Physis. 2007;17(1):4362. doi: https://doi.org/10.1590/50103-73312007000100004

11. Ministério da Saúde (BR). Protocolo de manejo clínico do coronavirus (COVID-19) na atenção primária à saúde. versão 7. Brasilia, DF: Ministério da Saúde; 2020 [cited 2020 May 20]. Available from: https://saude.rs.gov.br/upload/ arquivos/202004/14140606-4-ms-protocolomanejo-aps-ver07abril.pdf

12. Gelbcke FL, Reibnitz KS, Prado ML, Lima MM, Kloh D. A práxis da enfermeira e a integralidade no cuidado. Enferm Foco. 2011;2(2):116-9. doi: https://doi. org/10.21675/2357-707X.2011.v2.n2.108

13. Constituição da República Federativa do Brasil de 1988 [Internet]. Braślia, DF; 1988 [cited 2020 Sep 12]. Available from: http://www.planalto.gov.br/ ccivil_03/constituicao/constituicao.htm

14. Conselho Federal de Enfermagem (BR). Resolução COFEN/0554/2017. Estabelece os critérios norteadores das práticas de uso e de comportamento dos profissionais de enfermagem, em meio de comunicação de massa: na mídia impressa, em peças publicitárias, de mobiliário urbano e nas mídias sociais. Brasilia, DF: COFEN; 2017 [cited 2020 Sep 12]. Available from: http://www. cofen.gov.br/wp-content/uploads/2017/07/Resolução-554-2017.pdf 
- Acknowledgments:

We would like to thank the National Council for Scientific and Technological Development (CNPq), Brazil, Process No. 312339/2017-8 for the support.

\section{- Authorship contribution:}

Marcos Venicio Esper - Conceptualization, Investigation, Methodology, Writing - original draft, revision, and editing.

Jeferson Santos Araújo - Conceptualization, Investigation, Methodology, Writing - original draft, revision, and editing.

Manoel Antônio dos Santos - Conceptualization, Investigation, Methodology, Writing - original draft, revision, and editing.

Lucila Castanheira Nascimento - Conceptualization, Financing, Supervision, Investigation, Methodology, Writing - original draft, revision, editing.

\section{- Corresponding author:}

Marcos Venicio Esper

Email: marcos.esper@usp.br

\section{Associate editor:}

Dagmar Elaine Kaiser 